Brit. J. prev. soc. Med. (1956) 10, 63-74.

\title{
HUMAN BIOLOGY AND HUMAN SPEECH
}

\author{
BY \\ LANCELOT HOGBEN \\ From the Department of Medical Statistics, University of Birmingham
}

\section{(1) ISOGENS AND ISOPHONS}

Since a discussion at the British Association, several scientific and other journals have given wide publicity to views which Darlington published in 1947 under the title "The Genetic Component of Language". In their book, "The Elements of Genetics", Darlington and Mather (1949) again set forth this thesis. A large number of their readers will accordingly gain the impression that it is already acceptable to scholars equipped with specialist knowledge to assess its credentials. Several philologists have expressed to me a contrary view, and are puzzled because biologists seemingly give silent assent to Darlington's thesis. Otherwise, I should be reluctant to give utterance to misgivings that I myself share with some of my biological colleagues.

The word language, in the title of the publication cited, is unduly comprehensive. The topic of Darlington's memoir is indeed the distribution of two sounds, both familiar to an Englishman, to a Welshman, or to an Icelander, though neither of them occurs in spoken French, Swedish, Dutch, or German. They are the so-called voiceless dental fricative, represented in English orthography by TH as in thin and wreath, and the voiced dental fricative, also represented in English by $\mathrm{TH}$ as in then and writhe. Darlington compares the geographical distribution of speech communities in which these sounds are current with the geographical distribution of the triple allelomorph A-O-B. From this comparison, he draws categorical conclusions concerning the role of genetic differences with regard to the phonetic peculiarities of speech communities. Since the publication of Darlington's memoir, the issue has emerged again in a contribution entitled "Blood Groups, Ethnology and Language in Wales and the Western Countries", by Mourant and Watkin (1952), of whom the latter takes all responsibility for what is relevant to Darlington's theme.
In his original memoir, Darlington (1947) uses TH indiscriminately for the two sounds respectively represented by $b$ and $\delta$ in Icelandic and by $\theta$ and $\delta$ in the International Phonetic Script. Welsh orthography provides individually for each by combination: TH for the voiceless fricative in thin and DD for the voiced fricative in then. For typographical convenience, I shall here use TH as in Welsh and DH for Welsh DD. A fair statement of the conclusions drawn by Darlington from mapping the western world in terms of the distribution referred to above is as follows:

(i) the vocal organs of different human genotypes differ with respect to facility for making the TH-DH sounds;

(ii) the presence or absence of these sounds in the phonetic battery of a given speech community depends primarily on the predominance of genotypes so distinguishable.

The reader who is not familiar with the jargon of genetics may interpret this to mean that the substitution of $\mathrm{O}$ for $\mathrm{A}$ or $\mathrm{B}$ at the A-B-O locus of a particular human chromosome has a side-effect on the development of the vocal organs. It would be unjust to suppose that Darlington countenances any such crude interpretation of map correspondence. We may infer that he approaches blood group distributions merely as footprints of the track of inbred human communities in the remote past. On this view, local communities sharply distinguished by the frequency of the $O$ (or other blood group) gene bears testimony both to:

(a) the settlement by migrants of different stocks uncontaminated by subsequent interbreeding with later arrivals;

(b) the persistence of relict communities of earlier migrations side by side with others in which later migrants have more or less completely eliminated previous occupants. 
We may then plausibly assume that such stocks differed with respect to some gene frequencies other than those relevant to blood group classifications as such. Inter alia, Darlington postulates that such differences involve the structure and function of the speech organs. That they may do so is admissible. That they must is a leap in the dark.

Darlington (1947) himself sums up the factual basis of the theory he advances by stating:

the $O$ and TH maps agree more closely than the apparently confused history of Europe would seem to justify us in predicting. The isogens are almost exactly equatable with isophons (p. 282).

If we concede that an interesting correspondence emerges from a comparison of the maps, a glance at the lower half scarcely justifies so emphatic a statement about the facts at face value. Closer examination inspires greater caution. The black and shaded (Darlington's TH) areas on the left map include speech communities in which $\mathrm{TH}$ and $\mathrm{DH}$ are customary as in Britain (including Wales) and Iceland, TH alone as in Greece, or DH alone as in the Faeroes and some mainland Danish dialects. To be sure, the TH-DH dichotomy so labelled might not satisfy some experts in phonetics as sufficiently refined for the end in view; but its crudity merely reinforces the difficulty of deciding just how much we may legitimately infer from comparison of the factual content of the maps.

That comparison of this sort may suggest fruitful lines of inquiry is a proposition we may well concede; and we may leave to the expert in phonetics the last word with respect to Darlington's contentions, in so far as the facts impinge on phonetics as such. So far as it concerns the biologist, the issue would provoke no further comment if Darlington did not convey to the specialist who is not a biologist an erroneous impression about the legitimate claims of contemporary biological science. Again and again, the substitution of must for may well, or will for might, changes what would otherwise be a suggestive surmise into an assertion which other biologists might assuredly repudiate. Here are some examples (my italics):

(i) the causes of the differences (between languages), no less than the causes of the dissimilarities, must be partly genetic (p. 269);

(ii) a slight, and indeed only statistically identifiable, genetic difference will establish a linguistic difference (p. 272); (iii) what philologists have described as a substratum must be due to the integrated action of the genotypes of population (p. 282).

In the same temper, we note (without qualification) the assertion that "the group expresses its genetic character in dialect". Throughout this publication, as with less reserve in his Moncure Conway Lecture (Darlington, 1948), he seems to equate genetical to biological, and non-biological (when non-genetical) to mystical. The "discipline" of his own approach to linguistics and indeed to "modes of integration which underlie the development of all human culture ... offers a corrective to the ingenious theories (or fairy tales) which in the past have done less to help science than to embroil nations" (p. 283). He does not disclose which theories have embroiled nations more disastrously than the racialist dogmatism he espouses.

\section{(2) The Legitimate Domain of Genetics}

Such unprovoked readiness to dismiss as fairy tales levels of interpretation alien to our own preoccupations has a somewhat reminiscent flavour. In our youth, my own generation severally espoused the sects of mechanists, vitalists, and holists in the debate about whether all properties of living matter are ultimately explicable in physico-chemical terms. Most of us are now content to recognise that there are many profitable levels of interpretation, that it is rash to repudiate the possible coalescence of any two at some future date, and that it is fruitless to speculate about how far the process of unification will go before human life ceases on this planet. Maybe the metaphysical flavour of the term emergent evolution in the context of these jejune controversies partly explains the reluctance of some geneticists to concede that phenomena which genetics rightly claims as its province need not necessarily prove to be of paramount importance in connexion with rational inquiry into the changing pattern of human communities. Having outgrown mechanistic dogmas without acquiring a taste for the élan vital, entelechy, and the like, I myself - and many other biologistscan approach the vagaries of human speech with no disposition to dogmatize about what must or will happen in history, and with no inclination to prejudge what contribution (if any) genetics and neurosurgical research on the hemiplegias can respectively make to a deeper understanding of how languages change.

Genetics embraces the study of a characteristic common to living creatures and peculiar to them. If we exclude cellular respiration, we may say without reservation that no branch of experimental 
science takes as its province an aspect of nature more fitted to emphasize what is uniquely common to living matter. The sperm of a man or of a mussel, of a Jesuit or of a jellyfish, resembles that of a moss or of a liverwort more closely than that of a lobster. The human ovum and the ovum of the oyster resemble the ovum of a fern more closely than the ovum of an ostrich. The architecture of the chromosomes of man is as much like that of the sweet pea as that of a cuttlefish. Thus the geneticist can rightly claim that his chosen field of inquiry has a wide range of relevance; but the deliberate use of the word relevance in this context raises the question: relevant to what?

We now know what his followers did not yet fully realize in Darwin's time. Every organism produced by sexual generation starts life through the union of two gametes, whose material contribution to the developmental process subsumes what biologists commonly mean by inheritance. We also recognize, as his followers did not fully realize in Darwin's time, that individual characteristics are the result of a long process of interaction between the material constitution of the zygote and all the external agencies which operate in the course of development. Thus we can no longer meaningfully speak of the inheritance of characters. We inherit genes.

Characters which distinguish individuals may do so because individuals start off with different genes, because the agencies operative in the course of the development processes are different, or for both reasons. While we can meaningfully discuss how far, and in what situations, genetic differences contribute to character differences, it merely darkens counsel to speak, as does Watkin (Mourant and Watkin, 1952, p. 29), of "genetical characters of the vocal organs". To the objection that biologists who use such expressions themselves know what they mean, the appropriate rejoinder is that biologists who really know what they mean are careful to express themselves in a more meaningful way.

Prima facie there is therefore no reason to restrict the label biological to the explanation of individual differences within a framework of concepts specially relevant to the useful work of the geneticist, in contradistinction to the explanation of individual differences in a conceptual vocabulary relevant to equally useful inquiries variously undertaken by experimental embryologists, nutrition experts, or students of animal behaviour. The elucidation of the role of agencies participating in the developmental process is as truly part of the overall biological balance sheet as the elucidation of the genetic equipment with which the individual starts life. None the less, it is easy in retrospect to see how the disposition to prefer a genetic to a cultural interpretation of human differences got so firm a foothold in the ideologies of Darwin's disciples.

\section{(3) The Uniqueness of Man}

Less than a century separates us from a time when most well-educated persons in the western world accepted the first chapter of the Pentateuch as a literal (and inspired) account of human origins. Biological speculation in terms more commendable to human experience then encountered bitter opposition; and controversy forced biologists to justify the inclusion of Man in the animal kingdom by recourse to arguments more menacing to the credentials of their antagonists than relevant to the rationale of a taxonomical preference. Inevitably in the heat of debate, it seemed all-important to emphasize what Man shares with other animals, the more so because so much about Man's peculiarities eludes what we ordinarily agree to call physiological inquiry.

In this setting, biologists had good reason to believe that differences with respect to the genetic makeup of animal species are primarily responsible for differences of behaviour which distinguish one (e.g. a social ant) from another (e.g. a solitary bee.) So the analogy between locally restricted species of social organisms with distinctive anatomical facies and human communities, distinguished both by different culture patterns and by minor somatic peculiarities such as skin colour or hair, disposed of any embarrassing temptation to remedy lack of intensive study of what is peculiar to the human ecological system. Nor need we blame our illustrious forefathers for what should now seem to be rashness of judgment on such matters. Our situation is otherwise. No one with educational pretentions still subscribes to Ussher's chronology. With Ussher and Bishop Wilberforce so far in the rear, and with no less detachment than that with which our predecessors could examine what distinguishes the mouse as one animal species from all others, we ourselves ought now to be able to ask: What distinguishes our own from other animal species?

We have far to go before we can fully discuss in the language of physiology the characteristics which make Man unique; but we shall not attain such a goal (if at all) unless we recognize what they are. In broad terms, they are easy to state and commendably biological considerations will not discharge us from the obligation to do so. Man is uniquely educable. In a unique sense, Man is a tool-making organism. In a unique sense, Man is an animal capable of informative communication through speech. Because of 
this threefold uniqueness, a single animal species can fashion a changing environment and hence a changing milieu for its own developmental process. Like any other organism, Man transmits his genes to the next generation. In a sense which transcends anything comparable that we may rightly say of any other species, Man also transmits experience to the next generation. Thus every change of the human environment through human interference signalizes a new accretion of transmissible experience and a new potential of further change.

Because of this, human society is a unique ecological system. It owes its essential peculiarities to idiosyncrasies on which the study of social insects has little or no bearing. While there is admittedly a prima facie case for the assumption that local differences of animal behaviour are finally traceable to differences within the proper province of genetics, there is no such case for the presumption that different patterns of Man's social behaviour are necessarily traceable to the same source.

In the last resort the mutation of chromosomes or of single genes is the pace-maker of organic evolution. The circumstances which determine its tempo and character include:

(a) the rate of mutation;

(b) the viability of mutant types vis à vis the immediately available environment or the secular changes of the latter;

(c) mating systems more or less propitious to the concentration of genotypes in pure lines in a particular ecological niche.

Since the human ecological system has a momentum sui generis, the recognition of these circumstances has no necessary bearing on the momentum of change in human society. That human beings are genetically variable is beyond dispute; but a rational examination of the relation of transmissible patterns of human behaviour, both to the diversity of the external environment in time and space and to the systems of mating peculiar to local communities, must take within its scope a potential of variation due to the circumstance that one generation passes on to the next its own experience and the experience of its predecessors.

If the beginnings of civilization testify to the formative role of the calendar in the first stages of writing, they also disclose, and with equal eloquence, how latitude, climate, and contour have been peculiarly propitious or otherwise to the universal necessity of time-keeping in communities which have refined the technique or have failed to do so. Though differences with respect to the genetic endowments of human communities are suppositious, such manifest external circumstances favourable to cultural efflorescence and to cultural stagnation are manifold. Nor can we appreciate how vast a range of possibilities they endorse if we discuss them singly and in isolation from the sum of acquired experience on which a particular community can draw. When the migrations of human stocks bring them into contact with otherwise similar circumstances, it will rarely if ever happen that two communities will respond within a comparable framework of traditional behaviour and equipment. Whether new circumstances are favourable to human inventiveness or otherwise, and if favourable, with what possible outcome, is an enigma which subsumes vastly diverse admissible solutions.

Thus the interplay of the diversities of environment on the stock-in-trade of transmissible experience encompasses a wide range of possibilities vis $\grave{a}$ vis the tempo and character of social change. The inertia of experience accumulated in dealing with a stimulus-complex which Toynbee calls the challenge of the environment may more or less effectively resist the impulse to deal with a new stimulus in a new way when other means of doing so are available. Failure to take advantage of a new situation may then deprive a community of the means of meeting the challenge of a different and later situation. The consequence of access to abundant root crops or of migration into an area where domesticable ungulates are available as beasts of burden may be quite different if the event follows, from what it will be if the same event antedates, a well-established cereal economy, and the adoption of a maize rather than a millet economy may initiate a train of events along a course with peculiarities of its own.

A little reflection on widely accessible and abundant sources of information thus suffices to justify the conviction that the joint relation of the human personality to its social and physical environment admits of many degrees of freedom, that minor variations of the sequence of otherwise similar stimuli may lead to widely divergent responses, and that anticipation of future consequences from definitive antecedents is rarely (if ever) a profitable undertaking. That the human ecological system has unique features, that it has a well-nigh limitless potential of change in the absence of the operation of forces which make some animal and some plant species more short-lived than others, and that genetic variability is never manifestly the pace-maker of such change are indeed propositions attested by the proper study of mankind. No knowledge we can gain from the study of plant or animal breeding can nullify 
them. Nor is such knowledge necessarily relevant to the evaluation of the changing character of human society. It would be rash to deny the possibility that genetic selection has played a part in the decline of civilizations; but it is more rash to assert that it has done so without a searching examination of other possibilities, the more so when an assertion perhaps plausibly relevant to a single instance embraces the history of all civilizations.

The pioneer work of Morgan and Muller on the architecture of the chromosomes is no less scientific because they took no stock of the structure of the protein molecule. By the same token, inquiry of the sort which Darryl Forde (1934) has undertaken in his Habitat, Economy, and Society is no less legitimate because the author sidesteps the level of genetical interpretation. Thus the view stated in the last two paragraphs is neither a political creed because Prof. Gordon Childe acknowledges his sympathy with the Marxist doctrine, nor a mystique because Prof. Arnold Toynbee acknowledges his sympathy with the Christian ethical tradition.

\section{(4) Human Biology and the Substratum of THE PHILOLOGIST}

Since speech in the informative sense of the term is so uniquely a human characteristic, the fact that local varieties of speech exist is an issue we should thus approach with a willingness to recognize the possible relevance of two ways in which human behaviour patterns propagate. There is little doubt that some individual speech defects are largely attributable to genetic make-up in the only intelligible sense of the term, i.e. that environmental agencies contributory to the developmental process do not have the casting vote. Undoubtedly, also, normal children of parents who speak any known language acquire the different speech habits of a foster community if transferred thereto in babyhood. We therefore start our inquiry with the knowledge:

(a) that speech communities may conceivably be distinguishable by preponderance of genotypes equipped (ceteris paribus) to make particular sounds with greater or less ease;

(b) that human beings, by and large, can and do make any of the sounds peculiar to one or other variety of human speech if subjected sufficiently early to an appropriate range of stimuli.

With both these considerations before us, we have no excuse for simplifying the problem unduly. It is conceivable that a ruling family with a lisp might impose a fashion of speech on a whole tribe, or in time on a nation, but only so because others were more educable. Even if we had definite evidence of such an occurrence, we should be wrong to erect a law of nature on a single instance without asking what other conceivable circumstances have contributed to recorded regional changes of the sound pattern at other times and elsewhere. We may presume with little reservation that different genotypes on the same diet are more or less susceptible to dental caries, and it is highly likely that the early onset of dental caries among parents or grandparents will influence the speech habits of children. What speech habits children acquire from more or less edentulous elders will then depend likewise on the food habits of the community; but we have as yet no certain knowledge about how far prevalence of early dental caries in different communities is mainly attributable to the genetic make-up of such communities, to the drinking water available, or to the diet restrictions imposed by climate, custom, and soil.

It is therefore difficult to read a meaning into Darlington's contention:

If transferences of language from one people to another had been, or could be, accomplished without change, there would be no ground for inventing or seeking a genetic component of language.

The issue is not whether there is or is not a genetic component of language in the sense that genetic variability does or does not come into the picture of linguistic change at some stage. The only rationally debatable issues are:

(i) In what situations, if any, is genetic variability the pace-maker of such change?

(ii) By what means at our disposal can we identify such situations conclusively?

Circumstances contributory to the sound shifts (e.g. Primitive Germanic $t$ to $t s$ or to $s s, p$ to $p f$ or to $f$ in High German, and Indo-European $k w$ to $p, s$ to $h$ in Welsh) which have played so prominent a role in the devolution of language have prompted a host of speculation, and if comparative linguistics has still no simple story to unfold, its reticence is not due to lack of plausible hypotheses. Many known circumstances influence both the recognition of sounds and the transmission of sounds by tuition, e.g. distortion of the human voice by wind and echo in glens and on mountains, the local tradition (if any) of ritual singing, or (for reasons already stated) the fluoride content of the local water supply. No such hypothesis is intrinsically repugnant to sound biological doctrine. Any one such hypothesis may have a limited relevance without prejudice to an equally limited relevance of another; and any one of them is intrinsically 
as plausible as a hypothesis which puts the genotype into the centre of the picture.

In the absence of opportunities to test the credentials of a hypothesis by recourse to a decisive experiment, most of us are all too ready to luxuriate in the comfort of any explanation to which the only alternative is reservation of judgement; but reservation of judgement is not the only alternative to the hypothesis that genetic variability has played a predominant formative role in the differentation of human speech habits. If content with plausible explanations, we have an embarras de richesse. So we may reasonably expect that a hypothesis of the type which is the topic of this essay pinpoints a situation which admits of no conceivably plausible interpretation in other terms. With this expectation, let us return to Darlington's thesis.

As stated, Darlington rests his case on the correspondence between the occurrence of the TH-DH sounds and the predominance of the O-genotype. Whether phoneticians and specialists in comparative linguistics will fully subscribe to what he affirms about the former need not concern us here. If we provisionally accept the phonetic data as reliable, the conclusion we may rightly infer from such correspondence remains a highly debatable issue. An entirely correct assessment of the data disclosed by mapping blood groups frequencies is not without hazards, since we know so little about the relation of climate and other circumstances to mutation rates; but we may provisionally concede that isogens bear testimony in a rough and ready way to the migration of different human stocks in the more or less remote past. If so, we must equally concede that the separation of the main linguistic families had taken place before, or was taking place coextensively with, such migrations. With due weight to both assertions, we may then reason as follows:

(i) Human stocks involved in these migrations carried with them their speech habits as well as their genes;

(ii) When any migrant stock with its own local variety of speech intruded into a different speech community, circumstances would prove to be more or less propitious to the preservation both of the native stock-in-trade of genes and of the native pattern of speech.

Circumstances referred to last are admittedly obscure. There is still no entirely satisfactory explanation of why Latin so successfully supplanted the Osco-Umbrian dialects, Etruscan, Celtic, and Iberian, why the Low German dialects so successfully supplanted P-Celtic and Latin in Britain, why PCeltic established itself in Armorica (Brittany) so short a time after the withdrawal of the Roman legions, why the Norse conquerors of Normandy adopted French, and why the Frankish conquerors of Gaul did not leave a greater impress on the Gallic form of Roman speech. None the less, we can be confident about one thing. Unless the intruders exterminate or drive elsewhere the native stock, a brief interregnum of bilingualism is inevitable. During this transition period, some children will learn from their natural (or foster) mothers a form of speech which bears the impress of the native substratum.

The speech habits of the first generation may subsequently propagate themselves for an indefinitely long period because the human family is a unit for the tuitional transmission of a behaviour pattern no less than a unit for the material transmission of a gene complex. Each intrusion of another stock with different speech habits into the territory of a human stock with its own local variety of speech thus raises an issue sui generis. The warrior migrant may more or less completely drive his competitors before him into new territory, he may exterminate the native males and spare the females, and he may interbreed wholly with the latter or bring in his own womenfolk, who may or may not leave the up-bringing of their children more or less exclusively to native nurses. We can witness many such variants in the empires of our own times, each with its peculiar consequences. In short, the concept of substratum, as a philologist uses the term, is not a fairy tale merely because it admits of interpretation uncongenial to some geneticists. It is an inescapable inference from the little we know with certainty about man's unique neuro-muscular equipment.

By and large, a predominantly male intrusion will favour the persistence of the substrate, and if the native male survives as the helot of the migrant Herrenfolk, the impact of the migration both on the local variety of speech and on the local gene complex will be likewise minimal. With due regard to the multiplicity of such circumstances, which have no necessary connexion with genetic differences relevant to aptitude for the utterance of particular sounds such as TH and DH, we may still expect to find some measure of correspondence between the contribution of the migrant to the genetic make-up of the territory into which he intrudes and the suppression of the substrate speech pattern. If blood group frequency maps truly justify this expectation, such correspondence is therefore intelligible without recourse to the supposition that the pace-maker of linguistic change in human history has been the interplay of genetic differences relevant to the structure or function of the vocal organs. 
If we now ask what type of evidence would justify a confident preference for interpretation either at the level of man's unique educability or at the level of man's genetic variability, we must also give full weight to a circumstance too often brushed aside by animal-and plant-geneticists accustomed to deal with highly inbred stock reared in the highly standardized environment of a laboratory or of a research station. We approach the study of human genetics with no opportunities for standardizing our stocks, no opportunities for mating them at will, and no opportunities for ensuring a standard culture regimen. In a restricted class of situations, we may admittedly identify a gene-difference as such. These occur if its manifestation is recognizable by reference to some clear-cut marker characteristic, the exhibition of which is little influenced either by variation of the gene-complex as a whole or by realizable variation with respect to circumstances customarily attendant on the developmental process. Our initial handicaps need not then prevent us from identifying genotypes as such in accordance with the sufficiently exacting statistical requirements prescribed by the modern theory of the gene.

Such situations are rare; and the human geneticist is fortunate to be able to cite perhaps twenty rare diseases such as alkaptonuria or amaurotic (Tay-Sachs) family idiocy (juvenile and infantile), some few clear-cut idiosyncrasies, somatic (e.g. albinism) and functional (e.g. phenylketonuria and the thio-urea taste reaction), as also the various serological categories which include the A-O-B allelomorphic series. For reasons which I have sufficiently set forth elsewhere (Hogben, 1950, 1951), the belief that statistics, unaided by controlled experiment, can help us to assess the relative contributions of nature and nurture to human variability is a will-of-the-wisp. Since we have no freedom to undertake controlled experiment of a type sufficiently familiar to workers on the tobacco plant or on the fruit fly, the most we can hope to do is to make the best of controlled experiments which Nature and Society unwittingly conduct for us. Thus we can learn a little from the study of how identical twins reared apart and how unrelated foster-children reared together differ from and resemble one another.

\section{(5) The Experimental Approach}

If we now explore what opportunities Nature or Society confer on our quest to clarify how far genetic variability influences what sounds people of different communities utter with greater or less ease, we shall readily recognize two situations in which the human geneticist might profitably co-operate with linguistic scholars:

(i) Norwegians offered homes to German babies after the blockade of 1918, and British households took the custody of Spanish babies during the war which terminated in the overthrow of the Republic. Search would doubtless disclose other comparable situations which offer opportunities to throw more light on the interplay of ancestry (in the genetic sense) and acquired habits;

(ii) Many communities are bilingual; but our knowledge of the circumstances contributory to conformity of the speaker to a standard pattern of one or other official medium is not exhaustive. Familial studies of speech habits in such communities, if undertaken with due regard to the fact that human families transmit patterns of conduct as well as genes, might well disclose some worthwhile clues with respect to the role of the latter.

Since Darlington cannot be unaware of the ease with which the children of parents of one speech community seemingly assimilate the speech pattern of a widely different and geographically remote fostercommunity, he presumably endorses a gratuitous postulate latent in the speculations of physical anthropologists throughout the past century. Dogma asserts that human stocks were more sharply differentiated in ancient times. This is a hang-over from the days of the Darwinian controversy, before the views on phylogeny then entertained by zoologists came under the impact of experimental research on evolutionary processes. If we accept it, we may - but need not-assume that stocks whose migrations laid out the linguistic pattern of contemporary Europe in a period embracing culture levels from the palaeolithic to the chalcolithic were less educable with respect to speech formation than are their mixed descendants. Such a postulate is not demonstrably false; but it is assuredly gratuitous.

In pointing to such topics for further inquiry, I deliberately refrain from further comment, except to add that nothing we as yet know about them encourages us to believe that genetic differences between individuals play a dominant formative role in linguistic change. Meanwhile, dogmatic reasoning from self-evident axioms has nothing to commend it, unless it promotes intensive study of informative data such as the foregoing. Reasoning from first principles, however commendable, encounters pitfalls in genetics as in other branches of science, as a single example will suffice to illustrate:

Ceteris paribus, sex-linked lethal genes will promote a lower viability of the heterogametic than of the homogametic sex. Human vital statistics disclose a higher male 
than female infant death rate and a lower mean expectation of male than of female life. Since the male of the human species is the heterogametic sex, it is tempting to interpret this difference in terms of sex-linked lethals; and several genetic text-books in the past have cited this explanation as unexceptionable. If cetera were always paria, it would be adequate as such, and since the male is the homogametic sex among birds, we should then expect a higher death rate among female than among male chicks. On the contrary, Crew (1937-38) has shown that the male of the domestic fowl, like the male of the human species, is indeed the less viable sex.

\section{(6) The Hamites of Mynydd Hiraethog}

Watkin (Mourant and Watkin, 1952) undertakes a task more ambitious than that of Darlington. Seemingly, he does not concede that the conclusions discussed above are debatable, since (p. 26) he states:

recently, however, it has become apparent that race plays an important part in the determination of the phonetics of a given language.

As newly established by the work of Mourant and Watkin, the major factual data which we must accept as such are:

(i) In the Basque country, there is:

(a) a high frequency of the $O$ gene and a very low frequency of the B gene of the triple alleolmorph A-B-O series;

(b) a high frequency of the $\mathrm{d}$ gene $(0.55$ as against 0.30 elsewhere) of the closely linked Rhesus system C-D-E.

(ii) In North Wales the gene frequency of $O$ and $B$ is unusually high, that of A being inordinately low.

(iii) Regions of high $O$ frequency comparable to that of North Wales exist in the Scottish Highlands and in North Africa.

The authors draw their own conclusions as follows:

(i) There is a strong contrast . . . between the blood groups of the Basques who have tne lowest B frequency in Western Europe and the relict population in Wales ... There is some evidence that both of these populations have been present since palaeolithic times, and that both were once widespread (p. 23).

(ii) There appear to us reasonable grounds for the belief that, prior to the advent of Celtic speaking immigrants, the British Isles were inhabited by a people whose domain had at one time extended over a considerable part of Europe and North Africa... That the descendants of these people have, to this day, remained largely unmolested in those parts of our islands furthest away from the ancient land connexion with the continent of Europe seems demonstrated in the distribution of their ABO genes which singles them out from the other people of North Europe, excepting the Icelanders, but links them with the Berbers and other communities living on the Mediterranean shore and in the Middle East (p. 31).

As stated, Watkin takes full responsibility for the linguistic section of this memoir. Of the Basques, we read (p. 29) that they are:

probably a particularly pure relict race. They have a high $O$ frequency and a strongly developed $t$ h sound (or rather a $t$ th sound usually represented in writing by the letter $z$ ). If, therefore, only one stock has happened to carry the combination of many $O$ genes and the ability (my italics) to pronounce th, we should expect to find a large Proto-Basque element in all the high group $O$ th-speakers, and hence a high correlation between the typically Basque $d$-gene, the $O$ gene, and the $t h$-speaking character. Alternatively, the Basque may represent a fusion of an $\mathrm{O}, t h$-speaking stock with a $d$-stock.

Watkin goes further than Darlington when he here slips in the unqualified expression ability to pronounce, adds a new ingredient to the mixed bag of Darlington's TH, and may well convey to the reader not familiar with the literature a totally misleading impression by the implications of the term typically as applied to a gene whose frequency is at the 55 per cent. level in contrast with about 30 per cent. elsewhere. The alleged dispersion of a ProtoBasque population throughout Darlington's TH region in palaeolithic times is conceivable, and it is difficult to disprove because likewise difficult to establish. Inter alia, such hypotheses take no account of possible local differences with respect to the mutation rates of the blood group genes.

Since the Basque country, alone in Europe west of the Rhine and Danube, now preserves a tongue unrelated to the Indo-European family, no philologist will wish to dispute the possibility that it likewise preserves the speech of migrants who reached the Atlantic before tribes which spoke an IndoEuropean language did so. That its people have interbred little with their neighbours is likely enough; whence it is not strange that it has a characteristic pattern of blood group frequencies. In so far as the coincidence confirms expectations, it is not a trivial addition to knowledge; but the claim that the idiosyncrasies of Basque syntax and root stock are therefore attributable to the unique genetic equipment of the population is a non sequitur.

When Watkin proceeds to sort out the bearing of the blood group isolates of the Black Mountains of Carmarthenshire and of Mynydd Hiraethog on the linguistic history of the principality of Wales, he invokes a hypothesis traceable to the recognition of syntactical peculiarities which distinguish the 
Celtic languages from other Indo-European tongues west of the Urals. Regardless of the indications that some of these are common to the $Q$ and $P$ branches already differentiated before successive waves of Iron-Age migrants entered Britain during the period 750-250 B.C., Rhys (1879) put forward the suggestion that:

(a) the Celtic languages register the impress of a community indigenous in Britain before the arrival of the Celts;

(b) the speech of this aboriginal community was unrelated to the Indo-European family.

Rhys himself identified this community with that of the Picts.

Morris Jones, whose two and a half volumes (Phonology, Accidence, and an unfinished Syntax) on the Welsh language are a land-mark in Welsh philology, espoused and developed this thesis. His own views attracted widespread attention, becuase his memoir first appeared as an Appendix in a semipopular book, The Welsh People, published in 1900 by Rhys and Brynmor-Jones.

Modern genetics has thrown grave doubts on the type of phylogenetic speculation in which zoologists of Darwin's immediate following indulged. Though some human anatomists, in particular Wood Jones and Le Gros Clarke, have lately been more cautious, physical anthropology as a whole still lags far behind the current reticence of zoologists who hesitate to dogmatize about affinities and ancestries at taxonomical levels with less conspicuous pitfalls. It is therefore relevant to insist that Morris Jones started his inquiry confessedly with more than enough confidence in what physical anthropologists then had to say about the pre-Celtic population* of Britain:

The syntax of Welsh and of Irish differs in some important respects from that of the languages belonging to the other branches of the Aryan family. Professor Rhys suggested many years ago that those peculiarities are due to the influence of a pre-Aryan language. This suggestion led me to make the comparisons summarized in this paper. . . . We may suppose that the invading armies of Celts destroyed a large part of the aboriginal male population, and took possession of their wives, thus producing an amalgamated race, who, however, learnt their speech from their non-Celtic mothers. ... These non-Celtic inhabitants of Britain are believed by

\footnotetext{
* Rhys himself had expressed the surmise that the syntax of undeciphered Pictish Oghams would prove to be "of a type commonly found in agglutinative languages like Basque". This may explain a strange lapse of Watkin, who states: (my italics) "the agglutinative character of the language (Irish) is fundamental" (p. 32). This would suggest that the Hamitic agglutinative, as philologists commonly use the term. They are not. Neither is Irish.
}

anthropologists to be of the same race as the ancient Iberians, and to have migrated through France and Spain from North Africa, where the race is represented by the Berbers and the ancient Egyptians. ... If there is evidence that this is so-and we find on comparison that neo-Celtic syntax agrees with Hamitic on almost every point where it differs from Aryan - we have the linguistic complement of the anthropological evidence, and the strongest corroboration of the theory of the kinship of the early inhabitants of Britain to the North African white race (Rhys and Brynmor-Jones, 1900, pp. 617-618).

The Appendix cited concludes with a restatement of the author's motif:

That the pre-Celtic inhabitants of Britain were an offshoot of the North African race is shown by the cranial and physical similarity between the long-barrow men and the Berbers and Egyptians ... The idea of comparing neo-Celtic with Hamitic was suggested to me by the view just mentioned as to the origin of the Iberians. If they are the same people as those who speak Hamitic languages, then the explanation of neo-Celtic syntax which Basque has failed to supply was to be sought for, it seemed to me, in Hamitic (Op. cit., p. 640).

One does not need to be a philologist to recognize that the method by which Morris Jones seeks to validify the Hamitic affinities of the putative Pictish impress is a type of reasoning more congenial to the legal profession than to men of science. Since he invites us to retrace our steps to a period far too remote to bequeath clues to those sound shifts which conceal a common stock of roots most indicative of linguistic affinity, he is unable to sustain his thesis by the type of evidence to which philologists customarily attach most importance. Accordingly, he falls back on Welsh-Coptic similarities with respect to accidence and syntax. Similarities with respect to accidence are not impressive unless we reject out of hand the possibility that the Celtic languages have retained archaic features which the earliest IndoEuropean languages (Sanskrit, Greek, Latin) known to us through literature had lost. Two of the syntactical similarities mentioned depend on dubious assumptions about Primitive Indo-European word order, and one emphasized by Watkin merely draws attention to a widespread peculiarity of languages which have no extensive informative (in contradistinction to Bardic and sacred) literature. To the nonWelsh-speaking beginner there is certainly a mnemotechnic interest in the six parallel uses of Welsh YN and Egyptian EM; but Watkin does less than justice to the theory he invokes when he remarks* (last two italics mine):

* This is erroneous. The Welsh $y n$ always introduces a predicative substantive (e.g. Y mae ef yn ddyn) and always a predicitave adjective (e.g. Y mae'r dyn yn hen), never an attributive (e.g. Gwelais yr hen ddyn). 
$Y n$, like the Egyptian $e m$, is used after the verb 'to be' to introduce not only an attributive substantive but also an attributive adjective.

One might mention the occurrence of several other mishaps when Watkin departs from the ipsissima verba in his summary of the Appendix cited. Speaking of the role in Welsh of temporal particles in the periphrastic conjugation (a usage by no means peculiar to Hamitic and Celtic), he writes:

One must remember that a somewhat similar type of construction is to be found in English, though its source appears unknown, e.g. he is a-coming, a-hunting we will go. Probably it has filtered through to English.

Presumably, this concession to the formative role of habit in linguistic change signifies that the unknown source is a Welsh substratum; but the known source of such expressions does not confirm this supposition.*

However, my main purpose is here to emphasize a methodological issue which is common ground to philology and biology. Phylogenetic speculations have mnemotechnic value in both domains; but zoologists and philologists now alike concur in recognizing that debate must remain indecisive unless amply supported by the written record of the rocks or of the scribe. We can (and for mnemotechnic reasons justifiably may) draw up an impressive list of similarities between Amphioxus and a Polychaete or between Amphioxus and Balanoglossus. By itself either bears convincing testimony to a particular theory of the origin of vertebrates and either relegates each item of the alternative list to the status of an unresolved enigma. Writing in 1899, Morris Jones adopted the Balanoglossus methodology of his quinquennium. Since Gaskell (1908) showed that it is possible to defend with a richness of detail surpassing that of any previous theory a wholly untenable view of the origin of vertebrates, few zoologists have sustained much interest in the controversy. Pokorny (1927-30) apart, the same is true of the attitude now adopted by experts in comparative linguistics to the Hamitic substratum of Celtic.

That is why it is especially relevant to insist that Morris Jones admittedly set out to find justification for a hypothesis suggested by considerations which have no connexion with linguistics. Of the twelve similarities on which he lays stress, at least four are admittedly striking. So too is the evidence that "Mr. W. H." wrote Shakespeare's sonnets, in the absence

* Perhaps his first example recalls summer is $y$-comin, a dialect survival of is gecumen in Old English (mod. High German ist gekommen); the proclitic $a$ - in a-hunting (O. E. on huntynge), traceable to the earliest Anglo-Saxon form (an) of on, is authentically Teutonic. of an equally dispassionate statement of evidence to sustain the contention that someone else-including possibly Shakespeare himself-may also have done so. A biologist no less than a philologist should be able to detect how precarious is our foothold in the past when we rely on such selected similarities without investigating alternative possibilities, without giving due wieght to the difficulties they fail to resolve, and without adducing the support of tangible links with a remote past.

In a comparison between Q-Celtic and the Hamitic languages, Pokorny (1927-30) follows the same course as Morris Jones with the same initial preoccupation, but he more intrepidly assembles the ethnological and archaelogical evidence supposedly favourable to the identification of the cultural, temperamental, and physical idiosyncrasies of the white North African in the ancestral Irish stock. On this topic his views conform to a familiar pattern of though current in Germany during the inter-war period. As such they will impress only the reader already convinced that anthropologists have established a firm differential diagnosis of the temperament and mores of the ancestral Indo-Germanic master race.

Pokorny lists syntactical coincidences which allegedly reflect the quintessentially Hamitic character of the Celtic Weltanschaunng. He does not claim that his catalogue adds much (if anything) to that of his predecessor who decently refrained from prolix excursions into quasi-psychological guesswork propounded as eternal verities. The reader will infer what Pokorny himself claims to have contributed from the following:

Der Grund weshalb Morris Jones keinen Glauben gefunden hat, ist wohl darin zu suchen, dass er nur in rein skizzenhafter Weise einzelne Parallelen zwischen keltischer und hamitischer Syntax hervorsuchte und nebeneinander stellt, ohne die psychologischen sprachwissenschaftlichen Unterlagen, die allein seine These glaubhaft machen konnten, genugend gerauszuarbeiten $(O p$. cit., vol. 16, p. 110).

What Watkin says in support of the hypothesis put forward by Morris Jones and by Pokorny, conforms to the familiar pattern. Three obiter dicta invite comment:

(i) A line of Berber kings bore the name Idriss, whence Cader Idris supplies evidence of common WelshHamitic word stock.

Comment: It would be possible to find some single word like a Welsh place-name in almost any other language.

(ii) The Celtic languages, more especially Welsh, have a musical lilt which subserves the uses of ecstatic 
devotion, as the hwyl so like "the white North African's call to prayer";

Comment: A B.B.C. recording of the two (as cited by Morgan Watkin) would have more relevance to the debatable issue, had the listener the opportunity of comparing the $h w y l$ of the Welsh pastor with the chant of a non-Hamitic muezzin, or the intonation of Hereford market-place with den Svenska melodien in some parts of Scandinavia.

(iii) That the Scottish Picts (on authentic Roman testimony) were matrilineal (whence also not improbably the Gwydyll-Ffichti of North Wales) receives a ready explanation from the fact that one Hamitic tribe (the Touaregs) of equatorial Africa are likewise matrilineal.

Comment: This is true of early Mediterranean communities of several linguistic stocks and is still true of isolated communities in Africa, South Asia, Oceania, and America (for sources see Briffault (1927) The Mothers, and Bachofen (1861) Das Mutterrecht).

More detailed discussion of the linguistic theory which Watkin expounds would merely serve to emphasize an essential error of method sufficiently disclosed in what has gone before. There is a profound difference between seeking facts to test a hypothesis and selecting facts to illustrate its truth. When the relevant corpus of data is extensive and highly diverse, the second alternative may be wellnigh unavoidable as an expository device; but the first alone is an authentic recipe for research. That men of science confronted with a bewildering diversity of data in an unfamiliar field of inquiry sometimes overlook the distinction is explicable for a reason which any conscientious teacher of systematic biology will readily appreciate. A hypothesis which is false, or at best has nothing else to commend it, may still be a powerful mnemotechnic aid to the beginner, well worthy of use as a crutch to discard at a later stage of learning. That the Morris JonesPokorny theory undoubtedly lightens the beginner's footsteps through the mazes of Welsh grammar is thus a merit on all fours with the several merits of rival hypotheses to account for the origin of a land flora or of the origin of vertebrates. The analogy is the more pertinent because the credentials of the Morris Jones-Pokorny theory certainly do not command the widespread assent which Watkin appears to claim:

Philologists have pointed out that the Celts show in the whole structure of their language a close affinity to the language of the White Mediterranean peoples of North Africa (p. 32).

Even so, the acceptance of the Morris JonesPokorny theory does not force us to conclude that habits of speech peculiar to a putatively Hamitic aboriginal stock have persisted in Wales or elsewhere because its peculiar genetic make-up was propitious to their origin or because the peculiar genetic makeup of its descendants is propitious to their survival. Indeed, Morris Jones himself explicitly discarded any such supposition by emphasizing the role of the mother vis a vis transmission of a substrate idiom when the first victorious migrants were largely males. If indisputable evidence were available to sustain the affinity of the syntax of the Gwyddyl-Ffichti with that of Berber dialects, the only comfort the human geneticist could legitimately derive would be greater confidence in isogens as milestones of human migrations in remotely former times.

\section{(7) SUMmary}

1. The vast accumulation of data at blood transfusion depots and through large-scale field inquiries since the first World War has now placed at our disposal a substantial corpus of extant information about gene frequencies in geographically definable human communities. From these we may draw some highly plausible conclusions about the migration of human stocks in the remote past; but we can legitimately infer nothing of moment with reference to.the genetic peculiarities of such stocks, other than the preponderance of particular blood groups in one or other. Even so, legitimate conclusions must be tentative in the absence of more knowledge of circumstances which determine mutation rates at the relevant chromosome loci.

2. Progress in the study of Etruscan and in the decipherment of the Minoan syllabary (Literal B) discloses a brighter prospect of gaining knowledge about human speech in Europe before the advent of migrants with speech habits of the Indo-European type. We may therefore look forward to increasing opportunities for checking the conclusions which linguists reach by studying language itself against the conclusions to which blood group gene frequencies point, and vice versa. The value of such comparison will depend on how far the testimony from each source is compelling in its own domain of reference.

3. As an independent check on the validity of speculations about the migrations of people with different speech habits, conclusions to which blood group distributions lead us may prove to be highly illuminating. With that end in view, we should rightly welcome closer collaboration between the comparative linguist and the human geneticist. By the same token, biologists deserve our encouragement when they themselves take the initiative in promoting such collaboration. 
4. It is therefore the greater pity that reckless speculation about the formative role of genetic variation vis à vis linguistic change, and unprovoked readiness to label alternative levels of interpretation as unscientific, should deepen the gulf between specialties each with its own legitimate framework of interpretative relevance.

\section{REFERENCES}

Bachofen, J. J. (1861). "Das Mutterecht". Krais and Hoffmann, Stuttgart.

Briffault, R. (1927). "The Mothers: a Study of the Origins of SentiBriffault, R. (1927). "The Mothers: a Study of the Origins of
ment and Institutions", 3 vols. Allen and Unwin, London.

Crew, F. A. E. (1937-38), Proc. roy. Soc. Edinb., 58, 73.

Darlington, C. D. (1947). Heredity, 1, 269.
Darlington, C. D. (1948). "The Conflict of Science and Society". Conway Memorial Lecture. Watts, London.

and Mather, K. (1949). "The Elements of Genetics". Allen and Unwin, London.

Forde, C. Daryll (1934). "Habitat, Economy, and Society". Methuen,

London.
Gaskell, W.H. (1908). "The Origin of Vertebrates". Longmans Green, London.

Hogben, L. (1950). "The Methodology of Medical Genetics", in "Research in Medical Science", ed. D. E. Green and W. E. Knox, pp. 63-93. Macmillan, New York.

(1951). "The Formal Logic of Nature and Nurture". Acta genet. (Basel), 2, 101.

Jones, J. Morris (1900). Appendix B in "The Welsh People", by J. Rhys and D. Brynmor-Jones, pp. 617-641. Unwin, London.

Mourant, A. E., and Watkin, I. Morgan (1952). Heredity, 6, 13.

Pokorny, J. (1927). Z. celt. Philologie, 16, 95, 231, 363. (1928). Ibid., 17, 373.

Rhys, J. (1879). "Lectures on Welsh Philology", 2nd ed. Trübner, London. London.
and Brynmor-Jones, D. (1900). "The Welsh People". Unwin, 